Endocrinol. Japon., Vol. 2, No. 1 (1955).

\title{
ON THE ROLE OF THE HYPOTHALAMIC-NEUROHYPOPHYSEAL NEUROSECRETION IN THE LIBERATION OF THE ADENOHYPOPHYSEAL HORMONES
}

\author{
KISHUO SHIBUSAWA, SUMIO SAITO, MIEKO FUKUDA, \\ TADAKAZU KAWAI AND FUJIO YOSHIMURA*
}

Department of Surgery, and Department of Anatomy*, School of Medicine, Gunma University, Maebashi

PLATES III, IV, AND V

In previous works (Shibusawa and Inou, 1951; Shibusawa, Inou and Itou, 1952; Shibusawa, Inou and Osono, 1953; Shibusawa, Inou, Osono and Yoshimura, 1953; Shibusawa, Inou, Osono and Toshima, 1954; Shibusawa 1955) we have shown that the antidiuretic substance is released in the blood as a result of the hypothalamic-neurohypophyseal neurosecretion immediately after surgery. The antidiuretic substance in the serum during the immediate postoperative period has been proved to contain the antidiuretic hormone in a larger portion, and we were also able to prove that the release of adrenocortical hormone begins to take place concomitantly with this liberation of the neurosecret, by assaying the blood level of 17-hydroxycorticoids. When the endogenous secretion of the antidiuretic hormone is hindered by destroying the median eminence, the secretion of the adrenal cortical hormone is also inhibited. It is shown that the Gomori's positive substance exists around the special blood vessels in the peripheral zone of the infundibulum, and it is possible that this substance enters the anterior pituitary via the portal vessels and plays its hypothetical role as a stimulator for the release of anterior lobe hormones.

The present experiments were undertaken to clarify the possible role of the hypothalamic-pituitary neurosecretion as the natural stimulator for the liberation of anterior pituitary hormones by exogenous administration of neurosecretory products.

\section{MATERIALS AND METHODS}

One hundred and fifty male albino rats and thirty mongrel dogs weighing $13-15 \mathrm{~kg}$. are used, keeping in a warm environment and good dietary conditions. Adrenocortical functions are determined by the estimation of blood level of 17-hydroxycorticoids (Nelson and Samuel's method) (1952), urinary 17-hydroxycorticoids by Thorn's method (1952), urinary 17-ketosteroids by Dingemanse's method (1952), and the eosinophile cell count in the peripheral blood by

Received for publication March 31, 1955. 
Hinkleman-Fischer's method. The histochemical analysis of the adrenal cortex are performed simultaneously by Sudan III, Levi-hematoxylin staining and Schultz-cholesterol methods. Anterior pituitary cells are stained by Azan, and the neurosecrets of the hypothalamic-neurohypophyseal system are stained by the Bargmann's modification of Gomori's chromium hematoxylin-phloxin and Gomori's aldehyde fuchsin methods.

The experiments are carried out in 3 groups of animals and human subjects.

1) Administration of Pitressin (Parke, Davis \& Co.) $500 \mathrm{mU}$. to the dogs, $200 \mathrm{mU}$. to the rats, and 2-4 U. to human subjects.

2) Administration of Pitocin (Parke, Davis \& Co.) $20 \mathrm{mU}$. to the rats and 3-5 U. to human subjects.

3) Administration of an Extract of human urine after surgery, possessing marked antidiuretic activity similar to Vasopressin. The Extract is as follows: The urine is adjusted to pH 5.1, $2 \mathrm{~N}-\mathrm{ZnSO}_{4}$ and $\mathrm{K}_{4} \mathrm{Fe}(\mathrm{CN})_{6}$ are added, and the precipitate that forms is collected. This precipitate is extracted with ammoniac ethanol, the ethanol is evaporated under a reduced pressure, and the residue is dissolved in dil. AcOH. The precipitate that forms on the addition of ethanol is discarded, ETOAc is added to the supernatant, and the precipitate thereby formed is submitted to paper chromatography, developing with the upper layer of $\mathrm{BuOH}: \mathrm{AcOH}: \mathrm{H}_{2} \mathrm{O}(4: 1: 5)$. The chromatograms, A, B, and C layers colored by ninhydrin is extracted with water. Fraction $\mathrm{B}$ seems to agree with the vasopressin activity.

\section{RESULTS}

\section{1) Effect of Pitressin}

After the intravenous drip injection of Pitressin, the blood level of 17hydroxycorticoids increases strikingly within thirty to sixty minutes, and continues for about two hours. The average maximal level: $14.03 \pm 1.11 \gamma / 100 \mathrm{ml}$. in the dogs, and $14.93 \pm 1.08$ in the human. Changes are uniform both in the human and in the dog. The number of circulating eosinophiles falls in the reversal way. The average maximal decrease of the eosinophiles: $65.83 \pm 7.11 \%$ in the dog and

Table 1. Effect of Pitressin

Blood 17-hydroxycorticoids Concentration

\begin{tabular}{|c|c|c|c|c|c|c|c|}
\hline & Minute & Before & 30 & $\begin{array}{c}60 \\
\gamma / 100 \mathrm{ml}\end{array}$ & 120 & 180 & 240 \\
\hline \multirow[t]{2}{*}{ Dog } & $\begin{array}{l}\text { Pitressin } \\
500 \mathrm{~m} . \mathrm{U} .\end{array}$ & $8.33 \pm 0.803$ & $10.47 \pm 1.24$ & $14.03 \pm 1.11$ & $13.50 \pm 0.89$ & $12.3 \pm 0.73$ & $8.63 \pm 0.59$ \\
\hline & Control & $8.70 \pm 0.102$ & $9.80 \pm 0.24$ & $9.55 \pm 0.29$ & $9.95 \pm 0.47$ & $10.3 \pm 0.10$ & $10.31 \pm 0.14$ \\
\hline \multirow[t]{2}{*}{ Human } & $\begin{array}{l}\text { Pitressin } \\
3 U .\end{array}$ & $8.07 \pm 0.04$ & $12.53 \pm 0.79$ & $14.93 \pm 1.08$ & $10.10 \pm 0.01$ & $9.11 \pm 0.21$ & $8.77 \pm 0.08$ \\
\hline & Control & $7.71 \pm 0.14$ & $8.25 \pm 0.10$ & $8.40 \pm 0.2 \varepsilon$ & $8.20 \pm 0.01$ & $8.13 \pm 0.01$ & $8.30 \pm 0.33$ \\
\hline \multicolumn{8}{|c|}{ Per cent fall in blood eosinophils } \\
\hline \multirow[t]{2}{*}{ Dog } & $\begin{array}{l}\text { Pitressin } \\
\text { group }\end{array}$ & 0 & $27.57 \pm 3.12$ & $45.67 \pm 5.27$ & $65.83 \pm 7.11$ & $56.77 \pm 4.30$ & $26.23 \pm 1.23$ \\
\hline & Control & 0 & $2.60 \pm 0.24$ & $+1.81 \pm 0.15$ & $+1.10 \pm 0.05$ & $+0.45 \pm 0.01$ & $0.05 \pm 0.007$ \\
\hline \multirow[t]{2}{*}{ Human } & $\begin{array}{l}\text { Pitressin } \\
\text { group }\end{array}$ & 0 & $33.43 \pm 4.25$ & $46.27 \pm 3.17$ & $33.57 \pm 3.01$ & $19.47 \pm 2.10$ & $9.30 \pm 0.21$ \\
\hline & Control & 0 & $2.11 \pm 0.31$ & $1.00 \pm 0.21$ & $1.15 \pm 0.14$ & $0.50 \pm 0.01$ & $+0.40 \pm 0.008$ \\
\hline
\end{tabular}


Table 2. Effect of Pitressin

Urinary excretion of 17-hydroxycorticoids

(human)

\begin{tabular}{|c|c|c|c|c|c|c|}
\hline Hour & -4 & 0 & 4 & 8 & $\mathrm{mg} / 100 \mathrm{ml}$. & urine \\
\hline Pitressin group & 0.51 & & 0.87 & 0.77 & & \\
\hline \multirow[t]{2}{*}{ Control } & 0.62 & & 0.52 & 0.58 & & \\
\hline & & . & 17-keto & & & (human) \\
\hline Pitressin group & 0.72 & & 0.62 & 0.65 & & \\
\hline Control & 0.71 & & 0.59 & 0.61 & & \\
\hline
\end{tabular}

$46.27 \pm 3.17 \%$ in the human subjects (Table 1). The urinary excretion of 17 hydroxycorticoids during 4-hour periods increases in the first 4 hours, significantly higher than that of the control, and for the next 4-hour periods. The urinary excretion of 17-ketosteroids increases slightly in the first 4-hour period, but the change is not significant (Table 2). From these data, it is believed that the adrenocortical secretion is stimulated by the administration of Pitressin.

The histological changes of the adenohypophysis and the adrenocortex are as follows: Lipid distribution in the normal rat adrenocortex is rather variable. In our materials there appeared a densely packed zona glomerulosa, separated by an arrow, relatively sudanophobic zone, i. e. transitional zone from the fairly uniformly dense zona fasciculata and reticularis. Three hours after the Pitressin injection, sudanophilic granules of the zona reticularis and inner zone of the fasciculata begin to decrease, and the transitional zone disappears. After 5 to 8 hours, there are found only a few sudanophilic granules in the cells of the zona fasciculata and zona reticularis. Number and size of the granules in the cells of the zona fasciculata decrease progressively with passage of time reaching their minimum within 8 hours after the injection (Fig, 1). The loss of lipid granules is usually confined to zona fasciculata and reticularis, and the degree of the change is comparable to that produced by the injection of 1-3 mg. of ACTH. Sudanophilic granules begin to restore thereafter and complete recovery occurs within 24 hours (Figs. 2 and 3).

In the adenohypophysis. three or four types of cells are usually distinguished, i. e. acidophile cells ( $\alpha$-cell), basophile cells ( $\beta$-cell), chromophobe cells ( $\gamma$-cell), and intermediate forms. Chromophobe cells are the main form and occupy about 50 per cent (Bremer and Weatherford) or 52 per cent (Heinbecker) of all the cells. Acidophile cells occupy about one-third, and basophile about one-sixth of all the cell component. Five hours after the injection of Pitressin, $\alpha$-cells and $\gamma$-cells become rich in the glands (Fig. 4). Eight hours later, number of $\alpha$-cells increases markedly and $\gamma$-cells also increases. Nucleus of $\gamma$-cells becomes larger than that of the control and cytoplasm of $\alpha$-cells looses its acidophile granules (Fig. 5). After 12 hours, the changes still continue. By 24 hours, distribution of the adenohypophysial cells become similar to that of the control (Fig. 6). 

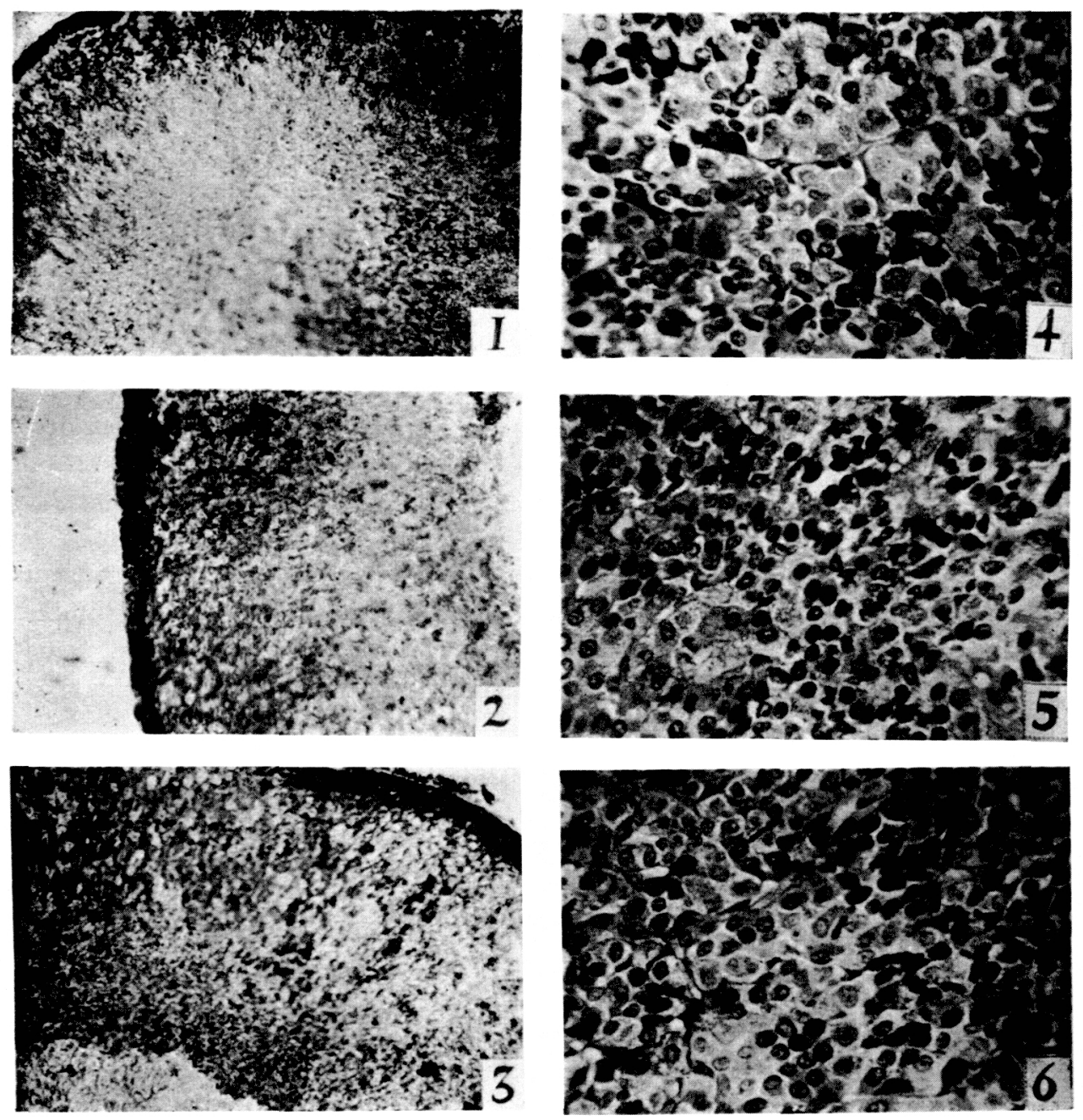

Fig. 1. Adrenal cortex, stained by Sudan III, 8 hours after the injection of Vasopressin. There are few granules in the cells of the zona fasciculata and zona reticularis.

Fig. 2. Adrenal cortex, stained by Sudan III, 12 hours afrer the injection of Vasopressin. Lipid granules are found only In the outer zone of the fasciculata.

Fig. 3. Adrenal cortex, stained by Sudan III, 24, hours after the injection of Vasopressin. Almost recovered.

Fig. 4. Adenohypophysis, 5 hours after the injection of Vasopressin. Note richer acidophile and chromophobe cells (Azan staining).

Fig. 5. Adenohypophysis, 8 hours after the injection of Vasopressin. Number and size of acidophile and chromophobe cells increase remarkably (Azan staining).

Fig. 6. Adenohypophysis, 24 hours after the injection of Vasopressin. Distribution of cells become similar to control (Azan siaining). 


\section{II) Effect of Human Urine Extract}

As stated previously, a highly antidiuretic activity is found in the urinary polypeptide fraction stained by ninhydrin, when the postoperative human urine is submitted to paper chromatography. Using this Extract, the following experiments were undertaken:

Table 3. Effect of the Urine Extract

Blood 17-hydroxycorticoids concentration

(dog)

\begin{tabular}{lccrccc}
\hline \hline Minute & Before & 30 & $\begin{array}{c}60 \\
\gamma / 100 \mathrm{ml} .\end{array}$ & 120 & 180 & 240 \\
\hline $\begin{array}{l}\text { Urine Extract } \\
\text { group }\end{array}$ & $8.53 \pm 0.77$ & $12.20 \pm 0.75$ & $13.83 \pm 0.8 \mathrm{~L}$ & $14.01 \pm 0.65$ & $12.76 \pm 0.73$ & $10.83 \pm 0.66$ \\
Control & $8.70 \pm 0.102$ & $9.80 \pm 0.24$ & $9.55 \pm 0.28$ & $9.95 \pm 0.47$ & $10.30 \pm 0.10$ & $10.31 \pm 0.14$ \\
\hline
\end{tabular}

Per cent fall in blood eosinophil cell count

(dog)

\begin{tabular}{llrrrrr}
\hline Urine Extract & 0 & $22.50 \pm 3.01$ & $31.30 \pm 4.27$ & $50.00 \pm 3.19$ & $42.10 \pm 5.03$ & $17.90 \pm 6.11$ \\
$\quad$ group & 0 & $2.60 \pm 0.24$ & $1.81 \pm 0.15$ & $1.10 \pm 0.05$ & $+0.45 \pm 0.01$ & $0.05 \pm 0.007$ \\
Control & 0 & &
\end{tabular}

After the injection of the Extract, 17-hydroxycorticoids level in the blood increases in 60 to 120 minutes and the changes thereafter show a similar curve as in the injection of Pitressin. The circulating eosinophiles decrease to the minimal level after 2 hours, the average fall of which is $50.00 \pm 3.19 \%$. After 3 to 4 hours, this decrease begins to recover to the level of $20-10$ per cent of the pretreatment values (Table 3). The urinary excretion of 17-hydroxycorticoids increases after 90 minutes, and continues for 150-300 minutes. A similar change is seen in the urinary excretion of 17 -ketosteroids (Table 4).

Table 4. Effect of the Urine Extract

Urinary excretion of 17-hydroxycorticoids

(dog)

\begin{tabular}{lrrrrr}
\hline \multicolumn{1}{c}{ Minute } & Before & 30 & $\begin{array}{c}90 \\
\gamma / 10 \mathrm{ml}\end{array}$ & 150 & 300 \\
\hline $\begin{array}{l}\text { Urine Extract group } \\
\text { Control }\end{array}$ & 51.1 & 50.5 & 62.3 & 121.4 & 58.5 \\
& 47.2 & 37.6 & 30.3 & 37.4 & 40.4 \\
\hline & Urinary excretion of & 17 -ketosteroids & (dog) \\
\hline \hline Urine Extract group & 81.0 & 69.2 & 127.3 & 134.0 & 61.2 \\
Control & 59.3 & 61.1 & 70.0 & 62.7 & 43.5 \\
\hline
\end{tabular}

After the injection of the urine Extract, the sudanophilic granules of the adrenocortex decrease, similar to that by the Pitressin injection. The loss of the granules is also confined to zona fasciculata and reticularis within 5 hours after the injection (Fig. 7) but after 8 hours, the loss of granules in the zona glomerulosa becomes significant and the transitional zone is not distinguished from the zona glomerulosa (Fig. 8). Recovery usually begins 24 hours after the injection.

The changes of the adenohypophysis are similar to those by the Pitressin injection. Eight hours after the injection, acidophile and chromophobe cells increase in number (Fig. 9).

By 12 or 24 hours, the chromophobe cells have larger nucleus (Fig. 10). 

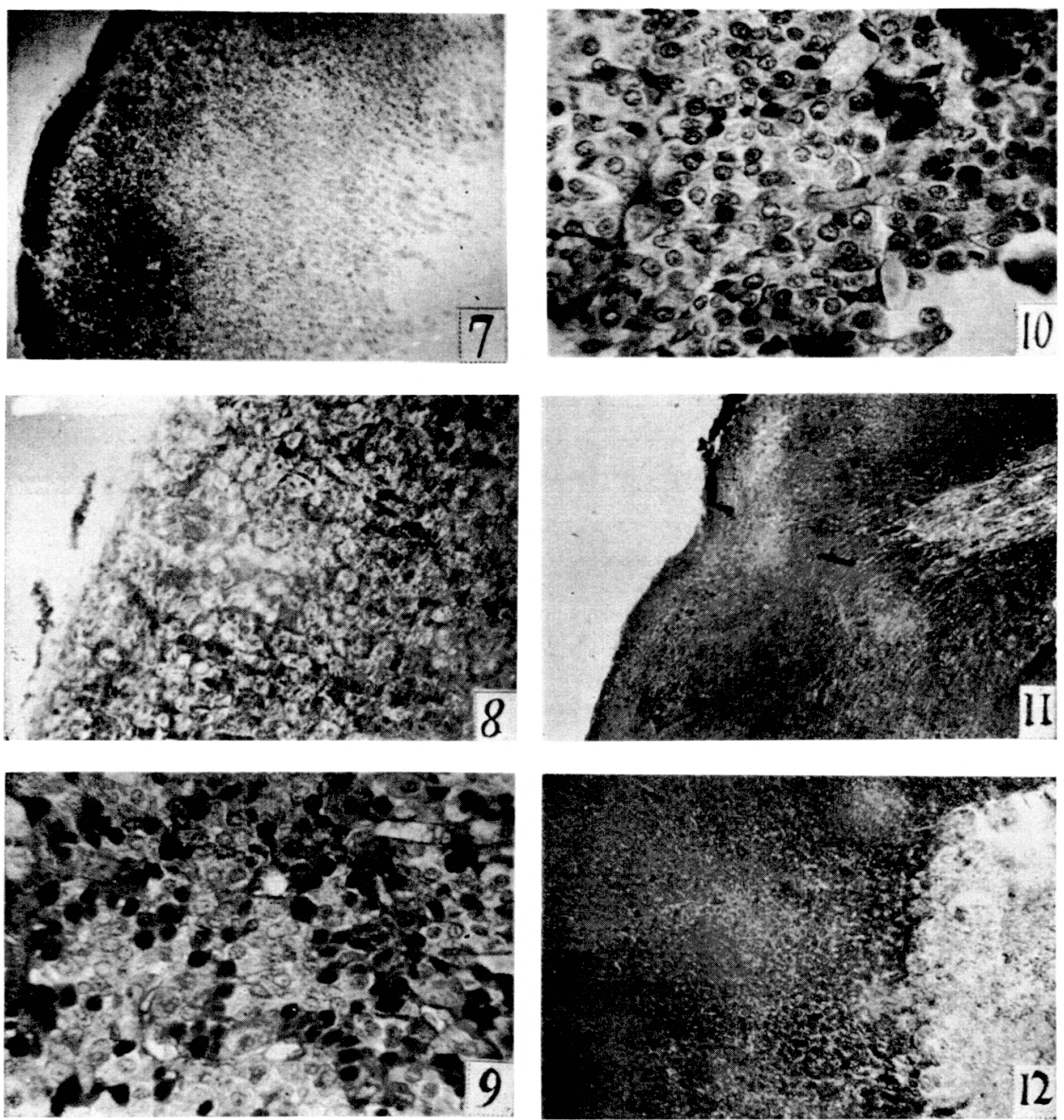

Fig. 7. Adrenal cortex, stained by Sudan III, 5 hours after the injection of the urine Extract. Decrease of lipid granules in the inner zone of the fasciculata.

Fig. 8. Adrenal cortex, stained by Sudan III, 8 hours after the injection of the urine Extract. Loss of sudanophile granules in the glomerulosa.

Fig. 9. Adenohypophysis, 8 hours after the injection of the urine Extract (Azan staining).

Fig. 10. Adenohypophysis, 24 hours after the injection of the urine Extract (Azan staining).

Fig. 11. Adrenal cortex, 5 hours after the injection of Oxytocin (stained by Sudan III).

Fig. 12. Adrenal cortex, 8 hours after the injection of Oxytocin (Sudan III). 


\section{III) Effect of Pitocin.}

The changes in the blood level of 17-hydroxycorticoids are not prompt and marked as by the injection of Pitressin (Table 5). Furthermore, there can not be found the significant fall in the blood eosinophiles (Table 5). The urinary excretion

Table 5. Effect of Pirocin

\begin{tabular}{|c|c|c|c|c|c|c|}
\hline \multirow{2}{*}{ Minute } & \multirow{2}{*}{ Before } & Blood 17-hy & \multicolumn{3}{|c|}{ 17-hydroxycorricoids concentration } & (human) \\
\hline & & 30 & \multicolumn{2}{|c|}{$60 \mathrm{\gamma} / 100 \mathrm{ml}^{120}$} & 180 & 240 \\
\hline Pitocin $4 \mathrm{U}$ & $7.67 \pm 0.21$ & $7.97 \pm 0.13$ & $8.10 \pm 0.12$ & $7.76 \pm 0.05$ & $7.57 \pm 0.18$ & $7.73 \pm 0.22$ \\
\hline \multirow[t]{2}{*}{ Control } & $7.71 \pm 0.14$ & $8.25 \pm 0.10$ & $8.40 \pm 0.23$ & $8.20 \pm 0.01$ & $8.13 \pm 0.01$ & $8.30 \pm 0.33$ \\
\hline & \multicolumn{5}{|c|}{ Per cent tall in blood eosinophile cell couni } & (human) \\
\hline Pitocin group & 0 & $4.87 \pm 0.41$ & $9.46 \pm 0.52$ & $5.57 \pm 0.81$ & $3.36 \pm 0.47$ & $4.13 \pm 0.21$ \\
\hline Control & 0 & $2.10 \pm 0.31$ & $+1.00 \pm 0.21$ & $1.15 \pm 0.14$ & $0.502 \pm 0.01$ & $+0.40 \pm 0.008$ \\
\hline
\end{tabular}

of 17-hydroxycorticoids for 24 hours does not vary markedly. However, by the injection of Pitocin solution, the urinary excretion of 17-ketosteroids increases markedly on the first to third day (Table 6). The chromatographic analysis of the urinary 17-ketosteroids reveals that the fractions I, III, V, and VI produce an exaggeration after the injection of Pitocin (Table 7). According to Pond and Dingemanse (1952), fractions I, III, IV, and V seem to be mainly chlorodehydroisoandrosterone, dehydroisoandrosterone, and etiocholanolone. They also claim that fractions IV and VII consist of 11-hydroxy-17ketosteroids. From these experiments, it can be seen that the increase of the excretion of 17-ketosteroids is mainly due to the gonadal androgens. It seems likely that Pitocin stimulates the secretion of the pituitary-gonadal axis.

Table 6. Effect of Pitocin

\begin{tabular}{|c|c|c|c|c|}
\hline & \multicolumn{3}{|c|}{ Urinary excretion of 17-hydoxycorticoids } & (human) \\
\hline Day & Before & $\frac{\mathrm{l}}{\mathrm{mg} / 24 \mathrm{th}}$ & 2 & 3 \\
\hline Pitocin group & $3.73 \pm 0.25$ & $5.30 \pm 0.73$ & $3.83 \pm 0.34$ & $4.12 \pm 1.31$ \\
\hline \multirow[t]{2}{*}{ Control } & $4.12 \pm 0.32$ & $5.55 \pm 0.49$ & $4.45 \pm 0.61$ & $5.15 \pm 0.51$ \\
\hline & \multicolumn{3}{|c|}{ Urinary excretion of 17 -kerosteroids } & (human) \\
\hline Pitocin group & $8.40 \pm 0.472$ & $13.83 \pm 2.14$ & $13.03 \pm 1.37$ & $11.90 \pm 1.37$ \\
\hline Control & $8.45 \pm 0.14$ & $9.07 \pm 0.35$ & $8.10 \pm 0.43$ & $8.25 \pm 0.15$ \\
\hline
\end{tabular}

Table 7. Effect of Pitocin

Estimarion of the separate fractions of urinary 17-kerosieroids (human)

\begin{tabular}{|c|c|c|c|c|c|c|c|c|}
\hline Fraction & 1 & II & III & IV & V & VI & $\cdot \mathrm{VII}$ & VIII \\
\hline Before & 4.0 & 2.0 & 23.0 & 13.5 & 9.0 & 28.5 & 8.7 & 11.0 \\
\hline 1 & 3.0 & 4.0 & 33.0 & 21.0 & 34.0 & 41.5 & 12.5 & 7.0 \\
\hline 2 & 13.3 & 16.8 & 16.5 & 14.5 & 90.0 & 83.0 & 2.0 & 5.0 \\
\hline 3 & 7.3 & 9.6 & 12.3 & 8.3 & 28.5 & 35.5 & 6.0 & 8.0 \\
\hline
\end{tabular}



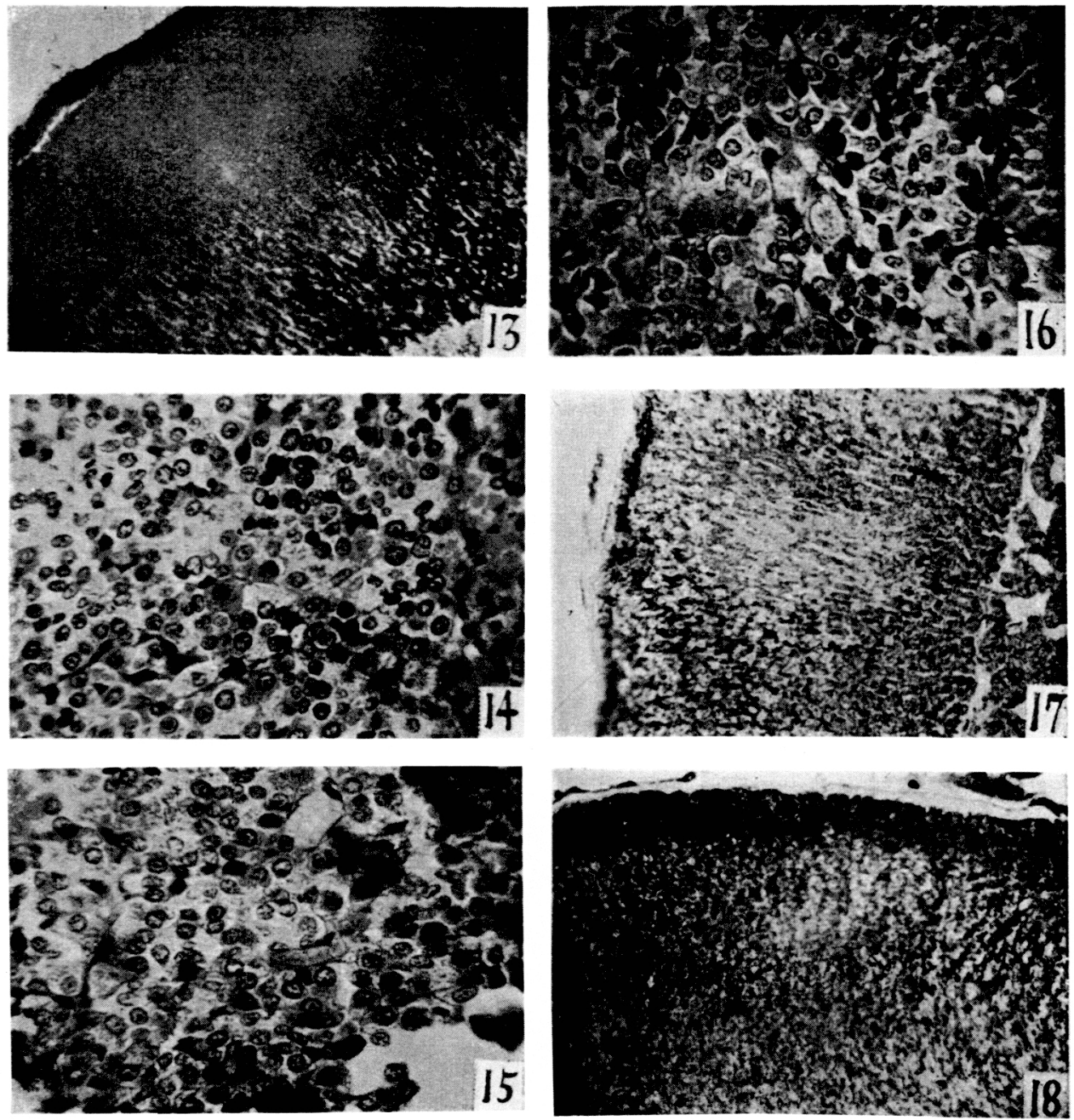

Fig. 13. Adrenal cortex, 20 hours after the injection of Oxytocin (Sudan III).

Fig. 14. Adenohypophysis, 8 hours after the injection of Oxytocin (Azan staining).

Fig. 15. Adenohypophysis, 12 hours after the injection of Oxytocin (Azan staining).

Fig. 16. Adenohypophysis, 24 hours after the injection of Oxytocin (Azan staining).

Fig. 17. Adrenal cortex, after the repeated injection (for 5 days) of divided dose of $1500 \mathrm{mU}$ of Vasopressin. The marked decrease of lipid granules in the zona glomerulosa, and disappearance of the transitional zone (Sudan III staining).

Fig. 18. Adrenal cortex, after the repeated injection (for 5 days) of divided dose of $200 \mathrm{mU}$ of Oxytocin. No remarkable change (Sudan III staining). 
After the injection of Pitocin, sudanophilic granules of the adrenal cortex do not decrease but rather increase in the zona fasciculata and zona reticularis. The cell of these zones are rich in lipid granules and seem densely packed (Figs. 11, 12 and 13). The changes of the adenohypophysis after Pitocin begin on and after 5 hours. More $\beta$-cells are recognized after 8 to 12 hours and are often difficult to distinguish from chromophobe cells (Figs. 14, 15 and 16).

IV) Effect of Repeated Injection of Pitressin and Pitocin.

The adrenocortex of male rats, killed 3 days after the injection of divided dose of $900 \mathrm{mU}$. of Pitressin, shows very remarkable changes. Sudanophilic granules decrease in the zona reticularis and outer zone of the fasciculata, and the glomerulosa becomes thinner. After the five days injection of divided dose of $1500 \mathrm{mU}$. of Pitressin, such changes of the adrenocortex become more marked. (Fig. 17).

The effect of repeated injection of Pitocin on the adrenocortex is not great. The sudanophilic granules are seen to be lying uniformly in the cells of three zones (Fig. 18).

\section{GOMMENT}

Recently, McCann and co-workers (1953) described the role of the supraopticohypophyseal system in the regulation of the adrenocorticotrophic secretion and suggested that the supraoptico-hypophyseal system controls the pitaitary ACTH output by releasing the antidiuretic hormone directly into the portal circulation. While Mirsky (1953, 1954) suggested that the antidiuretic hormone may serve as the hypothalamic neurohormone responsible for activation of the adenohypophysis in response to stress, because the discharge of $\mathrm{ADH}$ appears to precede the activation of the adrenal cortex and the release of ACTH is later. Scharrer (1954) considered that the hypothalamic-pituitary neurosecretion plays a role in the liberation of the adenohypophyseal hormones, since the Gomori's substance is present in the special vessel of the peripheral zone of the infundibulum and is transported via the portal vessel to the adenohypophysis. On the other hand, according to our previous works. the secretion of both ADH and ACTH cannot occur by the destruction of the median eminence even in the stressful stimuli. The increase of $\mathrm{ADH}$ secretion usually follows the increase of ACTH secretion during stress. The present study was carried out to determine whether the increase of the secretion of ACTH occurs by the injection of the $\mathrm{ADH}$ (vasopressin) exogenously. In our previous studies, the secretion of Oxytocin was also proved to increase with the release of $\mathrm{ADH}$ and the effect of the Oxytocin injected exogenously was also examined.

It has been proved, by the injection of Vasopressin and human urine Extract, that the elevation of pituitary-adrenocortical function occurs with the increase in the blood level of 17-hydroxycorticoids, decrease of the circulating eosinophiles, increase of urinary excretion of 17-hydroxycorticoids and 17-ketosteroids, and histochemical changes of adenohypophysis and the adrenocortex in the experimental animals.

Accordingly, Vasopressin is believed to be the prominent stimulator for the liberation of the pituitary adrenocortical hormone. On the other hand, exogenous 
administration of Oxytocin invites the hyperfunction of the pituitary-gonadal system ; Oxytocin seems likely to possess a stimulating activity for the pituitarygonadal function. It will be postulated that the hypothalamic-neurohypophyseal neurosecretion acts as the natural and potent stimulator for the release of certain adenohypophyseal hormones.

\section{SUMMARY}

1) Adult mongrel dogs, albino male rats, and human subjects were employed to test the effect of Vasopressin and Oxytocin on the adenohypophysis. The experiments were carried out in three groups: Pitressin-injected, Pitocin-injected, and human urine Extract-injected groups.

2) By the injection of Pitressin, the pituitary-adrenocortical system is stimulated and the secretion of ACTH increases.

3) After the administration of human urine Extract, possessing a striking antidiuretic activity, similar changes as by the Pitressin injection occurs in the function of the pituitary-adrenocortical system.

4) Pitocin seems to increase the secretion of the gonadotrophic hormone, judged by the fractionations of urinary 17-ketosteroids and histological findings of the adenohypophysis.

5) Brief discussions have been made on the concept that the anterior pituitary is stimulated by the hypothalamic-pituitary neurosecretion.

\section{REFERENCES}

1) Bremer, J. L. and H. L. Weatherford : "Text Book of Histology," Blakiston \& Co., 1948.

2) Cain, A. J. : Biol. Rev. $25: 73,1950$.

3) Dingemanse, E., G. H. Leonora and S. L. Hartoghkatz: J. Glin Endocrinol. 12 : 66, 1952.

4) Harrison, R. G. and A. J. Cain : J. Anat. 81: 286, 1947.

5) McCann, S. M. : Am. J. Physiol. $175:$ 13, 1953.

6) McCann, S. M. and K. L. Sydnor : Proc. Soc. Exp. Biol. Med. 87 : 369, 1954.

7) Mirsky, I. A., M. Stein and G. Paulisch : Endocrinology 55: 28, 1954.

8) Nagareda, C. S. : Fed. Proc. 10:96, 1951

9) Nelson, D. H. and L. T. Samuels : J. Clin. Endocrinol. 12 : 519, 1952.

10) Pond, M. H. : Lancet 2 : 906, 1951.

11) Reddy, W. J., D. Jenkins and G. W. Thorn : Metabolism 1 : 511, 1952.

12) Scharrer, E.: Experimentia 10: 264, 1954.

13) Shibusawa, K. and T. Inou : Rinsho Geka $6: 505$, 1951. (In Japanese)

14) Shibusawa, K., T. Inou and T. Itou: Trans. Conf. Endocrinol. Tokyo Univ. 2 : 208, 1952. (In Japanese)

15) Shibusawa K., T. Inou and S. Osono: Trans. Conf. Endocrinol. Tokyo Univ. 4: 83, 1953. (In Japanese)

16) Shiburawa, K., T. Inou., S. Osono., K. Yoshimura : Sogo Rinsho 10 : 304, 1953. (In Japanese)

17) Shibusawa, K., T. Inou., S. Osono and T. Toshima : Endocrinol. Japon. 1 : 89, 1954.

18) Shibusawa, K.,: "Nôkasuitai ", Ishiyaku Press. \& Co. 1955. (In Japanese)

19) Stoner, H. B. and H. N. Green : Brit. J. Exp. Pathol. 31 : 603, 1950.

20) Simms, E., M. Pfeiffenberger and P. Heinbecker : Endocrinology 49: 45, 1951. 